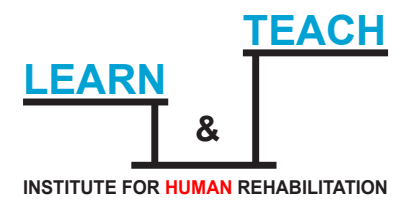

Human Research

in Rehabilitation

The International Journal

for education/rehabilitation

and psychosocial research

2020, Vol. 10 (1) 82-87

ISSN 2232-996X

DOi: $10.21554 / \mathrm{hrr} .042009$

\title{
WHICH VARIETIES OF ARABIC TO LEARN?
}

Review article

\section{Andjelka Mitrovic ${ }^{1}$}

${ }^{1}$ Department of Oriental Studies, Faculty of Philology, University of Belgrade, Serbia.

Received: $11 / 28 / 2019$

Accepted: 1/24/2020

\begin{abstract}
Teaching Arabic as a foreign language is very specific for different reasons. The main obstacle in searching for the optimal and effective teaching model for the Arabic language is the pronounced diglossia, a situation in which two languages or two forms of a language are used simultaneously under different conditions, formal and functional in a community, that is to say "higher" literary/standard Arabic and a "lower one" which encompasses numerous regional dialects. As a foreign language, Arabic has been taught all over the world, primarily at the university level, but the priority has always been given to a "higher language". It is also dominant in teaching nowadays but in creating curricula for teaching Arabic, more attention has been paid to relating the opposites of diglossia with the main speech dialects.
\end{abstract}

Key words: Arabic, diglossia, standard Arabic, speech dialect, teaching models, methodology

\footnotetext{
${ }^{1}$ Correspondence to:

Anđelka Mitrović, Ph.D., Department of Oriental Studies, Faculty of Philology, University of Belgrade, Serbia Studentski trg 3, Beograd, Serbia

E-mail: andjelkamitrovic@yahoo.co.uk
} 
Arabic is the official language in dozen countries which, despite all and very often decided religious, ethnical, geopolitical, economical and other differences make one relatively homogenous speech community, situated in the area of Middle East, i.e. Nothern Africa and a part of Asia. That religion is abundant in contrasts, different ethnical and religious groups, different traditions and spiritual wealth, high prosperity and utmost poverty, tolerance and hate... Middle East is the cradle of ancient civilizations Sumerian, Assyrian-Babylon, Egiptian, Phoenician, Aramaean, Judaism and others to which the debt of gratitude is to be given forever by the mankind for the inheritage of both spriritual and material culture. This is the birthplace of the three great monotheistic religions: Judaism, Christianity and Islam the announcement of which was declared in Arabic.

In economical respect, Middle East played an outstanding role particularly on the Silk Road due to the important caravan route and flow of the world trade. Then, there are numerous natural resources, first and foremost oil, the enormous capacities of which belong to some of the Arabic countries. Prosperity of the Arabic countries has been affected to a large extent by their touristic expansion, civilization contrast, historical monuments, magic of the desert as well as a lot of things that attract the visitors from all over the world.

Unfortunately, that great cradle of ancient civilizations and enormous natural resources has been a battlefield of numerous conflicts and wars as is a long lasting Arabic-Israel conflict, Iraqui War, the war and permanently smouldering crisis in Liban, Syria and Libia... In addition to this, some Arabic countries and their regimes have been mentioned nowadays as the main source, instigators and backers of the global terrorism.

Due to all this, the Arabic world has been for decades in the focus of various world economic, political, cultural and scientific streams. Therefore the importance of learning Arabic has grown in the last decades, in America and Europe particularly. A special attention has been drawn to the teaching of Arabic and methodology at many American and European universities as well as in some other institutions (eg. military centres).

According to many factors Arabic language teaching (ALT) as a foreign language is extremely specific for different reasons: because of the distinct diglossia, different writing system and the system of notification, different linguistic structure and so on. The basic obstacle in finding optimal and effective teaching model in case of Arabic is diglossia, i.e. simultaneous use of the two functional and formally distinctly devided varieties of one language, "higher", literary Arabic/standard Arabic language (ar. al-luga al-fuÒÎ) functioning as a widely accepted written language standard, mainly unique for the whole Arabic world learned through formal education at schools, and a "lower one", encompassing numerous regional speech dialects (ar. al-lug̉a al-'āmiyya). Apart from them, "there are a lot of intermediate varieties and registers, among which an elusive, but evidently 'transitional' or 'Middle Arabic' (ar. al-arabiyya alwusÔâ) stands out spoken by educated Arabs from remote parts of Arabic world, and which represents a specific functional mixture of a standard variety, 'general dialectisms' and the two speech varieties in contact.

Diglossia is a phenomenon of a society wide order so that the linguistic ability (competence and performance) of on average educated Arabs, naturally implies knowledge of both of its contrasing poles at which the knowledge of a "higher" variety (particularly performance) to a larger extent depends on the level of education (Tanasković, 1980, p. 64).

Diglossia is a universal linguistic phenomenon and is present, more or less, in all languages of the world. As far as Arabic is concerned the linguistic disunion is very pronounced and stable and nowadays all over the world it represents the language wit $h$ the most outstanding diglossia.

At the beginning of early 1960 's Arabic diglossia became the topic of the important and extensive linguistic, primarily sociolinguistic interests. 
Simultaneous use of the two or three formally and functionally distinctly separated varieties of the Arabic language within large Arabic speaking community has been envisaged in a qualitatively new way, first and foremost in the learning and description of various language idioms in specific parts of the Arabic world as well as in the organization of language use. ${ }^{2}$

Modern literary Arabic/Modern Standard Arabic, a descendant of the classical Arabic, although often defined as worldwide written language standard, is not completely unified for the fact that influence of the local dialects in different Arabic countries can be felt in it. It is the language of media, science, literature, the language of Inter Arabic communication, the language of spiritual and cultural inheritance of the Arabic-Islamic civilization and above all the language of Islam and Qur'an .

The speech dialects of Arabic have been existing for long in Arabic speech community, in fact, since the time bygone (Janković, 1978, p. 152). Various Arabic tribes on Arabic Peninsula spoke them several centuries before Christ and their features stood the test of time through

\footnotetext{
${ }^{2}$ Diglossia has become in the Arabic world a subject of interest of numerous arabists-linguists, particularly since the moment of great development of sociolinguistic research. Great contribution to the description of the wholesome speech community of Arabic, as well as of its particular parts was given by: S. J. Altoma (The Problems of Diglossia in Arabic, Cambridge-Massachusec, 1969), A. F. Beeston (The Arabic Language Today, London, 1970), W. Diem (Hocharabisch und Dialekt im Arabischen: Untersuchungen zur heutige arabischen Zweisprächigkeit, Wiesbaden, 1974), Ch. Ferguson („Diglossija“ / Word, 15, 1959, p.325-340; Myths about Arabic / Rdeadings in Sociology of Language, ed. J. Fishmann, London, 1970, p. 375-381), R. S. Harrell (The Phonology of Colloquial Egyptian Arabic, New York, 1957), T. F. Mitchell (Colloquial Arabic: The Living Language of Egypt, London, 1962), V. Monteil (L'Arabe modern, Paris, 1960), R. Nakhla, "L'Arabe classique et les dialectes néoarabes" / ETI, I, 1938, p. 15-25, II, p. 148-168), N. Tomiche ("Les Parlers arabes d'Egypte" / Études d'orientalisme dédiées à la memoire de Levi-Provinçale, T. II, 1962, p. 767-779; Les Parlers arabe du Caire, Paris, 1964). Srđan Janković, arabistlinguist from Sarajevo for deacades has systematically studied this topic and wrote many important studies: „Diglosija - sociolingvistički fenomen suvremenog arapskog“ / Radio Sarajevo - Treći program, 20, 1978, 142-177, „Polovi diglosije u arapskom“ / Prilozi za orijentalnu filologiju, 14, 1975, 283-300 i Diglosija u savremenom arapskom: Na materijalima književnog arapskog i egipatskog kolokvijalnog arapskog (Doktorska teza, Sarajevo, 1975).
}

centuries becoming rich and naturally developing under the influence of different social factors. On the basis of a large number of spoken dialects a unique language model was created - coine having the most outstanding features of the spoken language. Nowadays the spoken dialects are the essential and active factor in the Arabic reality. Dialects vary from country to country, moreover from region to region within one country. Within it colloquial speech of a city differs from that of the village, nomadic from the one of the inhabitants in settlements, the spoken language of different social classes and groups, ethnic and religious communities... The differences between literary Arabic and Egyptian dialect exist on all linguistic levels. On phonetic-phonological level: some sounds have different pronunciation and the vowels "e" and "o" come into view as well. On morphological level the changes have been shown in the change of some verbal and nominal paradigms, in gender and number, then with imperfect and perfect conjugation, as well as with the complex tenses, in the distribution of auxiliaries, in the pronoun system, in a system of cardinal numbers, with the adjectives and in the use of the elative case. As far as syntax is concerned, changes are perceptible in the organization of a simple and complex sentence. The differences are prominent on the lexical level.

A dialect is, in fact, a mother tongue of every Arab. This is the language of every day communication. The mass media in Arabic countries instead of fighting for the correct literary language, use the dialects to great extent in different broadcasts so that the spoken idioms are frequently present in radio and television programmes. Although the Arabic writers introduce significantly the dialects into literature at the beginning of $20^{\text {th }}$ century, we come across their traces in classic Arabic literature in the writings of such linguistic and literature authorities as were for example Jahiz (Ğāhiz, 768-869), or in poetry (i.e. muwaššấ, zağall). This variety is nowadays, due to its connection with everyday life, nearly unavoidable in the dialogues in stories, novelettes and novels because of the simple constructions, expressiveness but also because of the ability to render various thoughts and most subtle feelings. 
The presence of speech variety is even more outstanding in drama creativity. The plays have been woven only from dialogues through which life has been reproduced in a specific way and the personality traits of the characters have been revealed.

Therefore, for the plays with the topics from everyday life the dialects are the only natural and adequate way of describing characters. In such a complex linguistic situation the arabists of all generations used to ask a question: "Which Varieties of Arabic to learn? The answer to that seems to be everlasting question in Arabic studies, easy not in the least, especially lately. In the field of methodology no method, comprehensive and effective, has been discovered so far that would enable the acquisition and development of practically double linguistic competence as well as the adequate communicative competence. This does not mean that there were no such attempts and advances. Arabic has been taught all over the world at the university level and advance was always given to a "higher" variety, i.e. to the literary language - classical or contemporary respectively. Grammar-translation method was in that case an adequate approach as it enabled solid knowledge of grammatical structure, and above all, of strictly formalized morphology of Arabic characterized by a multitude of paradigms for derivation of various linguistic forms, within which there is a great degree of regularity and systematicic phenomena in language. Morphology is, in effect, the basic condition and a key to the acquisition of receptive knowledge (comprehension and reading of the written language), taking into account that this is the Arabic script of consonant type implying only the marking of consonants but of vowels only sporadically

It was only at the end of $19^{\text {th }}$ century that the first university courses of Arabic speech dialects were established. The National school for alive oriental languages (Ecole nationale des languages orientales vivantes) in Paris was one of the first universities in Europe and the World where the courses of eastern and western Arabic dialects were introduced in 1821.
Traditional teaching practice ${ }^{3}$ lasting for centuries which was focused on literary Arabic and grammartranslation method and which enabled the students to acquire the linguistic competence, primarily, morphological necessary for the development of both receptive and productive language skills at the end of $20^{\text {th }}$ century began to modernize with regard to the demands of modern era and modern societies, in which globalization, great expansion of communicative and informational technologies as well as the need for functional education and concrete knowledge have become dominant. In new educational models ,a special attention has been paid to fluency in foreign languages (Šotra, 2006) and that is the consequence of different reasons, primarily economical, as nowadays in the modern world and at the markets of the world - and Arabic market is particularly huge and has an outstanding status and importance - no business is possible without such knowledge.

Nowdays it is still Classical Arabic that is dominant in teaching, but in the course of the last three decades the teaching process and methods have been essentially modernized to meet various communicative needs and encourage acquisition of active knowledge that every teaching primarily aims at, above all in the sphere of of written production. Therefore modern textbooks were issued which besides obligatory textual component included various drills designed to help learners acquire vocabulary, grammatical categories and rules more efficiently and the elements of conversation as well.

\footnotetext{
${ }^{3}$ The first centres for Arabic language teaching have been established in Spain, France and Netherlands since 11th century and used for instructing catholic missionaries and preachers. Missionaries also deserved the merit for founding the first Arabic department. Namely, a missionary Guillanme de Postell (15101581) on his return from Orient and cessation of the missionary service, established the first university Arabic department in Paris in 1539. at French college (Collège de France). At the end of 16 th century a famous Leiden department was founded and in 1632. the Arabic department was established in Oxford, and since then many others were established all over Europe, primarily from religious reasons and then from economical. More about that in: cf.: M. Rodinson, "The Western Image and Western Studies of Islam" / The Legacy of Islam. Ed. by: J. Schacht, Oxford, 1974, p. 9-62.
} 
The Arabs themselves tend to contribute to the modernization of teaching Arabic as a foreign language. There are several renowned institutions in Arabic world which organize courses with different levels for the foreigners while at it appreciating modern achievements in methodology enabling acquisition of both receptive and productive knowledge. Among them the Instiute "Burgiba" in Tunisia surely stands out (Quasi, 1998). Standard Arabic is an excellent base for acquiring various spoken dialects as well as "the third" language used by educated Arabs in their communication, particularly with foreigners. In the last ten years while designing teaching models for Arabic, more attention has been paid to connecting poles of diglossia and also to the main speech dialects. But, due to the extremely complex sociolinguistic reality of the different speech community of Arabic, populous and specific in all respects, occupying vast territory on one hand and the new trends in language teaching on the other, it proves to be sophisticated and responsible task as the unique teaching method that would successfully solve all the problems in non-native reality and ensure uniform acquisition and development of total linguistic competences does not exist.

In the absence of ideal teaching method, the attitude of modern methodology is a practical one, having in mind that there are more paths to reach the aim of realizing teaching the language.

Therefore it is often necessary "to introduce an eclecticl approach, which contains various elements of different methods chosen to meet the needs of specific teaching situations" (Kristal, 1995, p. 374).

Decidedly eclectic approach is actual nowadays in the methodology of teaching Arabic as a foreign language which has only lately been more seriously defined in Europe and America since the focus is being transferred from linguistic structures and grammatical rules to the speech production and communication by introducing modern methods used in the teaching of other modern foreign languages (Scrivener, 2005; Richards \& Renandya, 2002; Scott, 2001; Nunan, 1998). It is clearly seen from the curricula of some of the European departments and particularly in the new textbooks in which together with functional textual components and different drills for acquisition and development of lexical components the elements of conversation were introduced. "As a general ideal aim of every foreign language teaching is acquiring of competence nativespeaker like or approaching that type of competence at least, it could be expected that the system of teaching Arabicmakes suchachievementof the described diglossic complex linguistic ability, possible" (Tanasković, 1980, p. 64). In a case of Arabic such competence is available to some extent only by introducing speech dialects. Our studies on Orient have always tended to keep pace with the world mainstream Oriental and Arabic flows as well as with those at home in order to fit in numerous reform processes and the needs of society. At this time we are active participants and witnesses to one more school reform in Serbia but also in Europe. Owing to the insight into the syllabuses of the relevant Arabic departments, the Arabic language teaching at the Oriental department of the Faculty of Philology in Belgrade has become updated and modernized by introducing new subjects/ courses as well as the new methodology in teaching the language. Since 2006/2007th, the students at the Section for Arabic language, literature and culture have been studying following the new radically changed plans and syllabuses. In terms of this, so far exclusively philologically structured syllabuses have been enriched with cultural-civilization dimension, that is with numerous subjects dealing with Arabic-Islamic culture and civilization. In addition to all that, linguo-cultural approach has been pointed out so that it will surely contribute to the corresponding development of overall linguistic competences of the students and their general sociolinguistic competence. From now on students will, owing to carefully chosen and graded pedagogical material, successfully develop specific linguistic levels acquiring grammatical units and lexis and developing and improving both spoken and written production in Arabic. At the same time systematically and thoroughly students will get to know all segments of Arab speaking community which is for the majority of students completely new and unknown field, i.e. they acquire all the necessary knowledge and information about 
geography, history, culture, art, philosophy, religious system/systems, geoeconomy, economy system of values in Arabic world, school system, law, ways of living, folklore, beliefs of the people, gastronomy... (Mitrović, 2009, 2008, 2006, 1997). In such teaching, courses of the Arabic dialects as Egyptian, Iraqi, Syrian, Maghrebi Arabic, which are optional subjects, are ranked high and have become very popular among the students. These two-term courses enable the students to get to know phonetic-phonological, morphological and syntactical features of the main Arabic dialects as well as to acquire lexis and phrases intended for everyday communication. So far rather scanty bibliography of the textbooks and dictionary literature for Arabic dialects have been increased lately and our contribution to that list is the textbook for Egyptian dialect Ekalem Masri 1 (Beograd, 2011), written by Iman Jarić, a lecturer for Arabic at the Oriental department at the Faculty of Philology in Belgrade. This manual consisting of 15 lessons in which the different topics and vocabulary have been presented through conversational context and life and situationally based contexts is useful and unavoidable companion for anyone who wants to learn the Egyptian dialect and to reveal its misteries. In order to develop communicative competence of the students of Arabic, as well as their overall linguistic competence, it is necessary to creatively develop all the courses permanently and to improve them in quality with the topics and materials. It should be particularly pointed out that at the Belgrade department there are excellent conditions concerning lecturers - lecturers from different important parts of the Arab world. As late as next year the students will have been able to learn new dialects - Libyan and Palestinian, and a decade old teaching experience has shown that there is place for four-term teaching of Arab dialects, a constitutional part of which will be the use of dialects in literature.

\section{REFFERENCES}

Janković, S. (1978). Diglosija - sociolingvistički fenomen savremenog arapskog. Radio Sarajevo - Treći program, 20, 142-177.

Kristal, D. (1995). Nastavni modeli“ / Kembrička enciklopedija jezika. Beograd: Current Practice, Cambridge.

Mitrović, A. (2008). Multidisciplinarnost u nastavi arapskog jezika. Multidisciplinarnost u nastavi jezika i književnosti: zbornik radova. Podgorica: Nikšić: Univerzitet Crne Gore, Filozofski fakultet, 213-228.

Mitrović, A. (2006). Nastava arapskog jezika i reforma obrazovanja. Nastava jezika u reformi obrazovanja: zbornik radova. Nikšić : Filozofski fakultet; Podgorica: Univerzitet Crne Gore, 138-160.

Mitrović, A. (1997). Nastava orijentalnih jezika na Beogradskom univerzitetu. Glossa, III, 1, 47-54.

Mitrović, A. (2009). Strategije čitanja u nastavi arapskog jezika. Individualizacija i diferencijacija u nastavi jezika $i$ književnosti. Nikšić: Univerzitet Crne Gore: Filozofski fakultet, 229-246.

Nunan, D. (1998). Teaching Grammar in Context. ELT Journal, 2(52), 101-109.

Qasi (Al-), Zahya, (1998). Al-'Arabiyya al-mu'āsira, Tunis.

Richards, J. C. \& Renandya W. A. (ed.) (2002). Methodology in Language Teaching: An Anthology of of Current Practice. Cambridge University Press.

Scott, T. (2001). Uncovering Grammar, Oxford.

Scrivener, J. (2005). Learnin Teaching, Oxford.

Šotra Katunarić, T. (2006). Kako progovoriti na stranom jeziku, Beograd.

Tanasković, D. (1980). Koji arapski jezik učiti?. Filološki pregled, 18, 1-4, 63-71. 